Geology for Civil and Environmental Engineers - Setting Priorities, Developing Desk Study Skills, and Case Study-Based Learning

Dr. Kevin G. Sutterer, Rose-Hulman Institute of Technology 


\section{Geology for Civil and Environmental Engineers - Setting Priorities, Developing Desk Study Skills, and Case Study-Based Learning}

\section{Introduction}

Knowledge of geology and applications of geology to civil and environmental engineering (CEE) works is important to many civil and environmental engineers. Geotechnical and geoenvironmental engineers in particular must be able to understand and apply various aspects of the geological sciences in their practice, but many other types of engineers also need to be confident in understanding and applying findings of geologists with respect to their projects. This includes managing civil or environmental aspects of foundation systems, tunneling, mining, construction materials, excavation, ground water, contaminant transport, seismicity, and mass movement, among many other applications.

Because of the importance of geological science to civil and environmental engineers, it is not unusual for some engineering programs to require a course in geology for all of its graduates. In other programs, a geology course is not required, but encouraged. Students and faculty members alike acknowledge the value of geology in a CEE education, as at least one course in geology is a common first choice for civil engineering students when selecting a science elective and is sometimes identified as a useful science elective for environmental engineering students.

In developing the currently recommended civil engineering body of knowledge ${ }^{1}$, the American Society of Civil Engineers (ASCE) did not specify that geology should be required in all civil engineering curricula, but did recommend one additional area of natural science for civil engineers beyond physics or chemistry. In so doing, ASCE suggested that geology would be one natural science that would be a typical choice for civil engineers. Support for a third science beyond physics and chemistry is also reflected in the civil engineering program-specific criteria for ABET accreditation, which requires that civil engineering programs include at least one basic science other than chemistry or physics.

\section{Context for Course Development}

There are currently no geology faculty members at Rose-Hulman Institute of Technology (RoseHulman). However, the Department of Civil Engineering (CE Department) has always strongly felt CEE students should be able to learn geology as a science elective, and has thus worked hard to see that geology is available to students at least once each year. The institute has been very supportive of the department in these efforts. For many years, a chemistry faculty member who is also a geologist taught an introduction to geology course at the institute, and the course was taken primarily by the civil engineering seniors as a science elective. Upon the departure of that faculty member, the CE Department was given primary responsibility for addressing continuation of a geology course at the institute. The availability of local geologists as adjunct 
instructors was considered, but each adjunct option carried uncertainty about regular scheduling of the class. Ultimately the CE Department decided to offer the course with one of its own faculty members (a geotechnical faculty) as instructor. The school leadership supported this decision and only required that, for accreditation reasons, the course remain $100 \%$ science content to avoid any doubt about the use of the course by students as a science elective.

The course was retitled Geology for Civil and Environmental Engineers. The CE Department faculty asked the new course instructor to design the course for sophomore CE students, and suggestions were made for content that could be useful for students entering courses in construction, environmental, geotechnical, materials, structural and water resources. Although the department does not offer a separate environmental engineering baccalaureate degree, civil engineering students who earn a minor in environmental engineering have course work equivalent to environmental engineering degrees offered at other programs, so consideration of how geology is a part of the environmental minor was an important part of course planning.

The new instructor identified a course text that could facilitate the desired learning ${ }^{2}$ without excluding learning that could be useful for other majors at the institute. While keeping in mind the learning identified by the CE Department faculty, learning activities were prepared that were generally consistent with the text and other similar courses offered by colleagues at other institutes. The ideal target course enrollment was identified to be 32 students or less in a single course section. However, because the course could only be offered once each year, the instructor was asked to try to admit any civil engineering sophomore or senior to the course. Thus, planned learning activities have to account for the possibility of a significantly larger course enrollment.

The course was offered following the format summarized above for three years (spring terms, 2009 through 2011). Course enrollments ranged from 32 to 59 students. The larger enrollments were during the first two years to accommodate juniors and seniors who had delayed taking the course until their senior year in keeping with prior tradition. Although, as described herein, the course was subsequently changed, those three years were important time for the faculty member to become familiar with all of the traditional course content, to observe how students' learning was demonstrated in later courses, and to reflect on prioritizing geology learning for civil and environmental engineers. The reflection included extensive discussion with other faculty members, industry colleagues, and students who had taken the class as sophomores and needed to apply the learning to subsequent courses.

Two observations were especially evident in reflecting on possible course revision. First, students struggle to develop a preliminary understanding of site geology through interpretation of the geologic literature, maps, and other geographic information. Lacking this understanding of how to interpret site geology based on desk study of the literature, all subsequent learning about applications of geology to CEE is weakened. Second, students greatly appreciate use of case studies for learning about geology. Students especially like failure case studies, but putting the learning in context with the use of any type of case study is highly beneficial, if well developed. 


\section{Setting New Learning Priorities}

Based on the reflections described previously, the instructor concluded a course redesign would lead to better learning about geologic applications to civil and environmental engineering works. This was initiated for implementation in the 2013. The redesign used the "backward design" approach of Wiggins and McTighe ${ }^{3}$. Even though the course instructor felt case-based learning and improvement to desk study learning would be important elements, this course design process would help set an appropriate amount of learning in these elements. After careful consideration of curricular priorities, the following course learning objectives were identified:

Students should be able to

1. demonstrate understanding of basic applications of geology to civil/environmental engineering

2. classify/rate rocks, minerals, and rock mass systems using standard methodology,

3. apply use of a geologic desk study model of a site

4. interpret the results of geologic explorations

5. discern anticipated subsurface conditions based on geologic information

For each of these, the instructor identified more specific learning objectives to help guide development of learning modules in the course. The instructor then decided how the students would demonstrate their level of learning for each of those learning objectives. Finally, decisions were made about how the learning should occur inside and outside of scheduled course meetings. This was not simple, as it required extensive revision of the usage of tests, case histories and project work, as well as most prior course modules. This dramatically altered the approach to course meeting time, students' learning on their own, and course grading. The instructor decided to use three different tools to foster and demonstrate learning:

- Tests are bested suited for evaluation of learning of terms, definitions and basic geologic principles relevant to most of the above learning priorities. This corresponds to Blooms ${ }^{4}$ levels 1 - Knowledge and 2 - Comprehension. Most such learning requires out of class memorization and reading, and benefits only a little from in-class activities. Much of the content on tests thus became the students' responsibility to learn on their own with only minimal review during class meeting time.

- Case study-based learning is appropriate to foster and demonstrate learning at higher Blooms ${ }^{4}$ levels 3 - Application and 4 - Analysis. Elements of each of the above learning priorities require work by students at these higher levels. This learning is not easily demonstrated with traditional timed tests. A selection of case studies of geologic failures was deemed a better fit for this higher level learning. Learning about failure case studies and how to analyze the failures also requires significant class time. Thus, a much greater emphasis on the use of case studies for in class activities was planned. 
- Project work that requires the students to apply geologic science to planning civil and environmental engineering projects shifts focus from failures to successes and emphasizes typical applications of geology to civil and environmental engineering. This includes demonstration of Blooms' ${ }^{4}$ level 4 - Analysis and 5 - Synthesis at a level appropriate for sophomores in the class. Project work is given some class time, but also requires mentoring outside of the class to foster learning.

A matrix was developed to map value of the different learning objectives to evaluation in tests, case homework, and project work. The matrix is shown in Table 1. The sum of the values is 1,000 total points, with the totals for each type of evaluation being 500 points for tests, 150 points for case homework and 250 points for project work. Note that one additional learning priority was added - "Students will demonstrate commitment to the learning through participation in the learning process inside and outside of class time." This was valued at 100 points, or ten percent of the overall grade. The course has now been taught twice using this new format, first in the Spring of 2013 and subsequently in the winter of 2013-14 (2014). The course schedule is provided at the end of this paper.

\section{Case Studies}

Case-study based learning is highly popular with students, very efficient in illustrating key points about application of engineering, math and science principles to engineering understanding, and readily available in the literature. In addition to sources in periodicals, recent compilations are also good sources of case studies. ${ }^{5,6,7}$ Failure case studies are particularly insightful for the students, and are sometimes especially well documented not only from a scientific perspective, but also from the perspective of social/community impact. Case studies can also be planned to foster learning about geology world-wide, forcing use of resources for desk study that may be less well-developed or at least more challenging to acquire. Global aspects of the CEE profession make this part of the learning important. There is an element to case study learning that can require helping students learn the value of persistent pursuit of understanding by accessing a variety of resources, a skill that can be helpful in all areas of engineering practice. However, in developing case studies for use by sophomores, course instructors must be careful not to turn the case into a "treasure hunt" by students, where the focus shifts to finding the right source rather than learning from the literature available. The cases must be designed to provide balance between learning about geology and learning about effective literature searches.

The instructor began implementing more case studies into the course in 2012. With the course revision, there are now seven different case study assignments in the class, including assignments for geologic failures of Teton Dam, Maxey Flats, Pisa, Malpasset Dam, Vajont Dam and the Rissa, Norway Landslide of 1978, among others. The first case homework assignment is for a proposed project on campus, and another is for a hypothetical environmental spill at a convenient geologic site identified by the students for an independent geologic field trip. 
Table 1. Matrix Map of Learning Objectives to Evaluation Tools for Acceptable Evidence of Learning

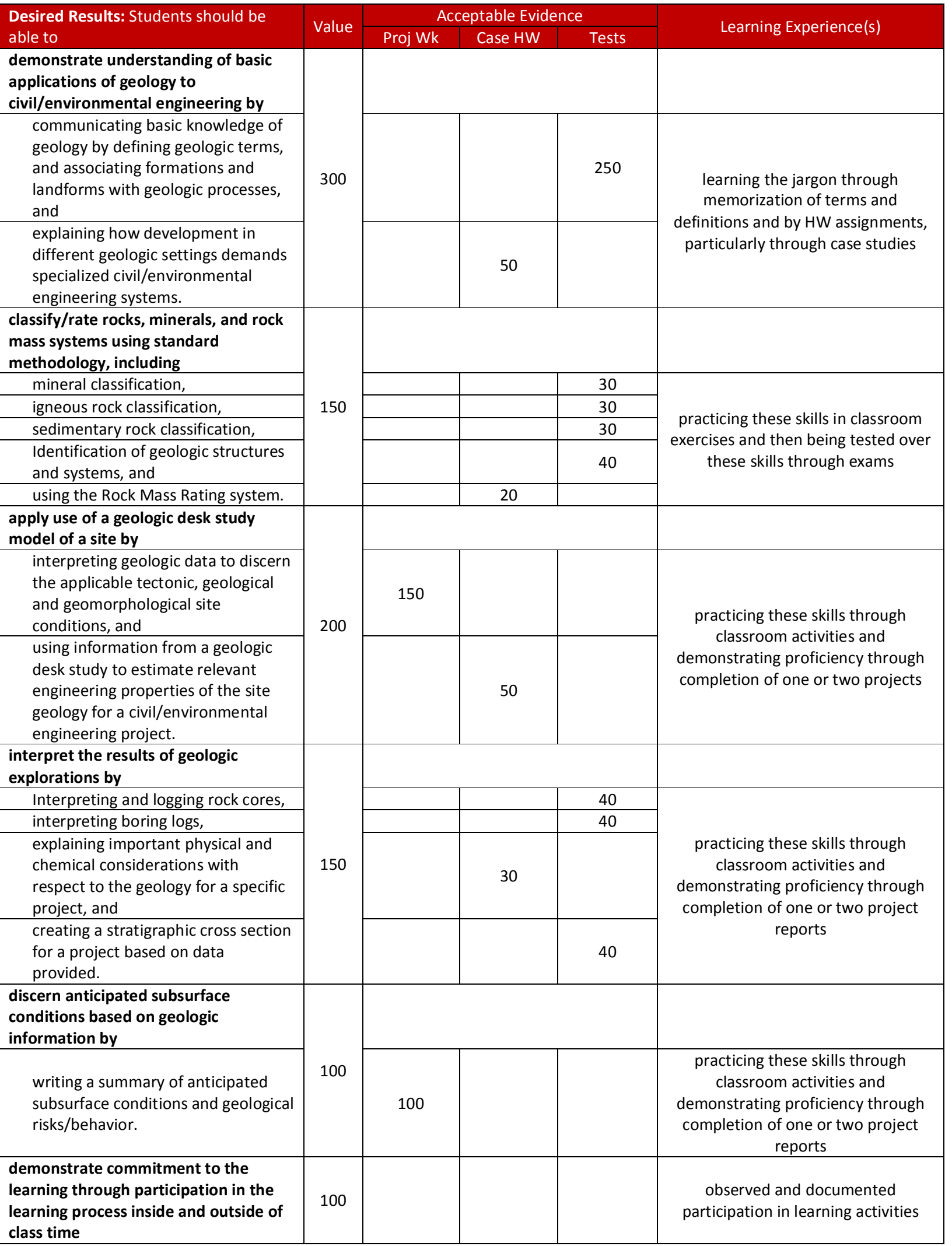




\section{Total Geological History}

Students' skills in the interpretation of geologic literature, maps, and other geographic information about site geology are very effectively demonstrated in the writing of geologic desk studies, particularly as a part of case study assignments. Before course revision, students were asked to develop two desk studies as a part of their course work throughout the term. Although some students' second desk study was slightly better than the first, some students did not show any improvement. It was clear in those cases that the students had not applied what was learned in the first desk study to preparation of the second. Both repetition and an emphasis on the preparation of desk studies using a consistent process seemed crucial to improve this learning. Through designed repetition, the students become familiar with development and use of geological desk studies for civil and environmental engineering works, and learn that geologic desk studies are an important part of virtually any civil or environmental engineering project.

An excellent systematic process for associating geologic characteristics with CEE design and construction challenges has been developed by Fookes, Baynes and Hutchinson ${ }^{8}$. The process, titled herein as Total Geological History, or TGH, is developed for use by experts for civil works projects, and guides the development of a geologic desk study that considers site tectonics, regional geology and local geomorphology. Expert users of TGH identify which of 10 tectonic models, 17 geological models, and 8 geomorphological models applies to their project, and how they interrelate. For each of the tectonic, geological and geomorphological models, TGH includes summaries which can help experts discern potential site challenges associated with the geology. TGH also identifies 31 geological case histories from which experts can learn about some of the typical challenges of the geology of the site through a case review. The TGH approach provides an excellent framework and supporting case study examples for skilled experts to follow. Once the geologic environment is understood, users can make informed choices about predicting likely stratigraphy and structure, estimating potential material properties, and planning subsurface investigations.

Limited use of TGH was implemented in the class in 2011. Unfortunately, the TGH method and materials are not ready for use by non-experts. The TGH work is written using British system geologic terms and systems, which differ from United States geologic terms and systems, and the work makes extensive use of geologic jargon that required frequent cross checking of definitions by beginners. While this promotes opportunities for deeper learning by patient learners, students find it difficult to dedicate the time and patience necessary to understand the work in its original form when working on case studies. As a part of the course revision, the instructor committed to teaching students how to use the method, linking its use to applications for case study work, and in developing clarifications of TGH to simplify its application. This work is still in progress. Meanwhile, despite its expert-focus, the use of TGH in the class provides a consistent process as guidance for development of geological desk studies. As confidence with TGH increases in the department, senior civil engineering students are beginning to use the TGH method with success for the early planning stages of their senior design project work. 


\section{Assessment of Learning}

Course development continues to be a work in progress. As already noted, the revisions were implemented in 2013, and have been used for a winter term offering of the course for 2014 . Students complete standard institute course evaluations for all campus courses each year. A summary of average responses to a few key questions relevant to this paper is shown in Table 2.

Table 2. Average Course Evaluation Ratings for Selected Questions About the Course

\begin{tabular}{|l|c|c|c|c|c|c|c|}
\hline \multicolumn{1}{|c|}{ Question } & 2009 & 2010 & $2011^{*}$ & $2012 * *$ & $2013 * * *$ & 2014 & $\begin{array}{c}\text { Dept. Avg. } \\
(2009-14)\end{array}$ \\
\hline $\begin{array}{l}\text { Quality of Learning } \\
\text { (5=excellent, 1=poor) }\end{array}$ & 3.48 & 3.54 & 3.30 & 3.64 & 3.60 & 3.83 & 3.83 \\
\hline $\begin{array}{l}\text { Course Workload } \\
\text { (5=much lighter, } \\
1=\text { much heavier) }\end{array}$ & 3.07 & 3.21 & 2.33 & 2.55 & 2.13 & 2.54 & 2.69 \\
\hline $\begin{array}{l}\text { Overall Course Rating } \\
\text { (5=excellent, 1=poor) }\end{array}$ & 3.43 & 3.71 & 3.11 & 3.82 & 3.80 & 3.75 & 3.82 \\
\hline
\end{tabular}

*Limited use of TGH implemented in the class

**Transition year - significant case study work added to the course in 2012

$* * *$ Course revisions described in this paper fully implemented

The Course Workload results in Table 2 show the impact of implementing use of TGH starting in 2011. In 2011 and 2012, students were asked to apply TGH to several cases and on tests, but without significant instruction on implementation of the process. These assignments did not account for the students' beginner skills in making use of content designed for use by experts. Along with the higher workload in 2011, students perceived a lower quality of learning and lower quality course. Students' perception of their Quality of Learning and the Overall Course Rating improved with the addition of case studies in 2012. Perceived course workload remained slightly high as the students continued to struggle with the application of TGH to the case studies. Although it is not evident in the results, the instructor noted application of TGH to more cases resulted in better skills in using TGH by the end of the term.

The results for 2013 and 2014 still demonstrate a high perceived course workload, although 2014 is closer to the department average. A review of student comments on course evaluations, input from students in less formal discussions, and instructor reflection suggests the high course workload is due to much more memorization for tests, rather than due to difficulties with TGH, but this was not directly assessed. The results do not indicate a significant change in Quality of Learning or Overall Course Rating when comparing the new course format with 2012. However, comments made by the students in their course evaluations, not included here for brevity, provided some evidence the new course format should be continued. The students continue to struggle with implementation of TGH, its link to estimating ground conditions, and thus also its link to application for planning CEE works. The instructor continues to work to evolve learning of TGH to fit the needs of beginners in geology. Better use of the case studies provided with the TGH literature should help with this. 
In addition to course evaluations, the instructor asked the students to complete an independent assessment and reflection after course completion in 2013 and 2014. Table 3 provides the numeric results of this assessment. Although 2013 assessments were submitted by 35 of the 38 students in that class, the digital results were lost in a power failure that damaged both the original submissions and the backup file. When the loss was discovered, students were contacted for resubmission, but only six assessments were voluntarily submitted. The results for 2013 are thus likely skewed and not likely representative of the entire class. The results are nevertheless provided as an early indication of student perceptions. For 2014, the results are given for the 25 students who submitted out of 31 students in the class.

Table 3. Student Ratings of Fulfillment of Learning Priorities

\begin{tabular}{|l|c|c|}
\hline Question (Rating: 5=Helped A Lot, 1=Did Not Help) & $\begin{array}{c}2013 \\
\text { Average } \\
\text { Rating } \\
\text { (N=6/38)* }\end{array}$ & $\begin{array}{c}2014 \\
\text { Average } \\
\text { Rating } \\
\text { (N=25/31) }\end{array}$ \\
\hline $\begin{array}{l}\text { To what extent do you think the course has helped you to understand basic } \\
\text { applications of geology to civil/environmental engineering? }\end{array}$ & 4.2 & 4.2 \\
\hline $\begin{array}{l}\text { To what extent do you think the course has helped you to learn to classify/rate } \\
\text { rocks, minerals, and rock mass systems using standard methodology? }\end{array}$ & 3.3 & 3.0 \\
\hline $\begin{array}{l}\text { To what extent do you think the course has helped you to learn to apply use of a } \\
\text { geologic desk study model of a site? }\end{array}$ & 4.7 & 4.5 \\
\hline $\begin{array}{l}\text { To what extent do you think the course has helped you to learn to apply } \\
\text { use of a geologic desk study model of a site? }\end{array}$ & 4.6 & 4.3 \\
\hline $\begin{array}{l}\text { To what extent do you think the course has helped you to learn to } \\
\text { interpret the results of geologic explorations? }\end{array}$ & 3.8 & 3.5 \\
\hline $\begin{array}{l}\text { To what extent do you think the course has helped you to learn to discern } \\
\text { anticipated subsurface conditions based on geologic information? }\end{array}$ & 3.7 & 3.4 \\
\hline
\end{tabular}

Slight differences between the results between 2013 and 2014 are disregarded because of the loss of most of the assessment data for 2013 described above. The findings indicate students felt strongly about their understanding of desk studies and were less confident about their understanding of classification and rating of rocks, minerals and rock mass systems. Comments provided by the students were generally supportive of the new form of the course. Students regularly reported they were initially unprepared for tests focused on out-of-class reading and memorization. Students also noted that although class time devoted to case studies was helpful, time consuming site-specific map and literature review followed by careful desk study preparation was still necessary outside of class.

One observation about the course is worth sharing, even though it is related to a course element from all six years and thus not a part of the course revision. This is with respect to the assignment that students complete a field trip to a significant geologic site on their own or in a group sometime during the term. This assignment was originally developed because the course enrollment was generally too large and schedules too restrictive for an instructor-scheduled field trip or field trips. Each year, most students have been very resistant to planning and conducting 
the field trip, but every year students report at the end of the term how greatly they appreciated the trip, once completed. This was even true during a very difficult winter weather season in 2014. Students have consistently urged the instructor to retain the field trip despite class resistance while the course is under way.

\section{Conclusions}

Geology is a crucial natural science for most civil and environmental engineers. Learning about geology can be more effective if the course content in this science course is targeted to civil and environmental works. When possible, CEE programs should thus consider learning priorities for geology knowledge in assisting course instructors in the design of an introductory geology course for civil and environmental engineers. Course design that takes into account the learning priorities and more specific learning objectives noted herein could lead to improved understanding of and confidence in appropriate geologic knowledge. Greater use of case studies, project work and a systematic approach to geologic desk studies is encouraged, when practical. The use of case studies and the Total Geological History process for preparing desk studies has improved knowledge and skills in the application of geology for CEE students. When valued knowledge, such as TGH, is available only in a form that requires expert skills, instructors should work hard to provide supporting materials to make the knowledge accessible to the skill levels of beginners. Instructors should remember to plan learning and experiences to help students not only with learning knowledge, but in developing skills that make use of the knowledge.

\section{References}

1. American Society of Civil Engineers (2008) Civil Engineering Body of Knowledge for the 21st Century: Preparing the Civil Engineer for the Future, $2^{\text {nd }}$ Edition, Prepared by the ASCE Body of Knowledge Committee of the Committee on Academic Prerequisites for Professional Practice, 191 pages.

2. Kehew, A. (2006) Geology for Engineers and Environmental Scientists, 3rd Ed., Pearson/Prentice Hall, 2006.

3. Wiggins, G. and McTighe, J. (1998) Understanding by Design, Association for Supervision and Curriculum Development (ASCD), Alexandria, VA.

4. Bloom, B., Englehart, M., Furst, E., Hill, W., and Krathwohl, D. (1956) Taxonomy of Educational Objectives, the Classification of Educational Goals, Handbook I: Cognitive Domain, David McKay, New York, NY.

5. Delatte, N.J. (2009) Beyond Failure: Forensic Case Studies for Civil Engineers, American Society of Civil Engineers, 406 pages.

6. Feld, J. and Carper, K. (1997) Construction Failure, $2^{\text {nd }}$ Edition, John Wiley and Sons, Inc., 512 pages.

7. Bosela, P., Brady, P., Delatte, N. and Parfitt, M.K. (2013) Failure Case Studies in Civil Engineering Structures, Foundations, and the Geoenvironment, $2^{\text {nd }}$ Edition, American Society of Civil Engineers, 125 pages.

8. Fookes P. G., Baynes F.J., and Hutchinson J.N., (2000), Total Geological History: A model approach to the anticipation, observation and understanding of site conditions, Invited Paper, Geoeng 2000 Conference , Melbourne Australia. 
Addendum: Course Schedule for Winter 2013-14

SCHEDULE

GEOL 270 Geology for Engineers and Environmental Scientists

\begin{tabular}{|c|c|c|c|c|c|c|c|}
\hline Wk & Date & Day & Mtg & & Rdg & Due $^{*}$ & $\%$ \\
\hline \multirow{4}{*}{1} & $12 / 2$ & Mon & 1 & \multirow{3}{*}{$\begin{array}{l}\text { Introduction to Geology and } \\
\text { Development/Use of Desk Study Models }\end{array}$} & & & \\
\hline & $12 / 3$ & Tue & 2 & & \multirow{2}{*}{ Chapters 2-3 } & & \\
\hline & $12 / 5$ & Thu & 3 & & & & \\
\hline & $12 / 6$ & Fri & 4 & Forensic Friday & & Case 1 & 3 \\
\hline \multirow{4}{*}{2} & $12 / 9$ & Mon & 5 & Refer to the Test 1 study guide & & Test 1 & 10 \\
\hline & $12 / 10$ & Tue & 6 & \multirow{3}{*}{$\begin{array}{l}\text { Introduction to preliminary site } \\
\text { engineering geology environment models } \\
\text { (Friday work day) }\end{array}$} & \multirow{3}{*}{ Fookes et al paper } & & \\
\hline & $12 / 12$ & Thu & 7 & & & & \\
\hline & $12 / 13$ & Fri & 8 & & & & \\
\hline \multirow{4}{*}{3} & $12 / 16$ & Mon & 9 & Mineral Classification & \multirow{3}{*}{ Chapters 3-6 } & Case 2 & 3 \\
\hline & $12 / 17$ & Tue & 10 & Igneous Classification & & & \\
\hline & $12 / 19$ & Thu & 11 & Sedimentary Classification & & & \\
\hline & $12 / 20$ & Fri & 12 & The "Is that coal in your stocking?" challenge & & & \\
\hline \multicolumn{8}{|c|}{ Christmas Break } \\
\hline \multirow{4}{*}{4} & $1 / 6$ & Mon & 13 & Forensic Friday & & & \\
\hline & $1 / 7$ & Tue & 14 & Refer to the Test 2 Study guide & & Test 2 & 10 \\
\hline & $1 / 9$ & Thu & 15 & \multirow{3}{*}{ Structural Geology } & \multirow{3}{*}{ Chapter 8} & & \\
\hline & $1 / 10$ & Fri & 16 & & & Proj 1 & 8 \\
\hline \multirow{4}{*}{5} & $1 / 13$ & Mon & 17 & & & & \\
\hline & $1 / 14$ & Tue & 18 & \multirow{3}{*}{ Geological Material Science } & \multirow{3}{*}{ Chapter 7} & Case 3 & 3 \\
\hline & $1 / 16$ & Thu & 19 & & & & \\
\hline & $1 / 17$ & Fri & 20 & & & & \\
\hline \multirow{4}{*}{6} & $1 / 20$ & Mon & 21 & Forensic Friday/Leonards' Method & & & \\
\hline & $1 / 21$ & Tue & 22 & Refer to Test 3 Study Guide & & Test 3 & 10 \\
\hline & $1 / 23$ & Thu & 23 & Soil and Soil Hazards & Chapter 10 & & \\
\hline & $1 / 24$ & Fri & 24 & \multirow{2}{*}{ Earthquakes } & \multirow{2}{*}{ Chapter 8} & & \\
\hline \multirow{4}{*}{7} & $1 / 27$ & Mon & 25 & & & Case 4 & 3 \\
\hline & $1 / 28$ & Tue & 26 & \multirow{2}{*}{ Groundwater } & \multirow{2}{*}{ Chapter 11} & & \\
\hline & $1 / 30$ & Thu & 27 & & & & \\
\hline & $1 / 31$ & Fri & 28 & Forensic Friday & & & \\
\hline \multirow{4}{*}{8} & $2 / 3$ & Mon & 29 & Refer to the Test 4 study guide & & Test 4 & 10 \\
\hline & $2 / 4$ & Tue & 30 & \multirow{2}{*}{ Mass Movement and Slope Stability } & Chapter 13 & & \\
\hline & $2 / 6$ & Thu & 31 & & Cnapter 13 & & \\
\hline & $2 / 7$ & Fri & 32 & Case HW5 Work Day & & & \\
\hline & $2 / 10$ & Mon & 33 & & & Case 5 & 3 \\
\hline 9 & $2 / 11$ & Tue & 34 & Geological \& Geomorphological Processes & Chapters 14-16 & & \\
\hline 3 & $2 / 13$ & Thu & 35 & & & & \\
\hline & $2 / 14$ & Fri & 36 & Forensic Friday & & & \\
\hline & $2 / 17$ & Mon & 37 & Refer to the Test 5 study guide & & Test 5 & 10 \\
\hline 10 & $2 / 18$ & Tue & 38 & & & & \\
\hline 10 & $2 / 20$ & Thu & 39 & TBA & & & \\
\hline & $2 / 21$ & Fri & 40 & & & Proj 2 & 17 \\
\hline
\end{tabular}

${ }^{*}$ Case and Project work due by $8 \mathrm{a} . \mathrm{m}$. in the Moodle Drop Box on the day indicated. 